\title{
Effect of Adenine, Cytidine and Guanosine on the Expression of the SOS System in Escherichia coli
}

\author{
By MONTSERRAT LLAGOSTERA, * RICARDO GUERRERO, \\ ANTONIO VILLAVERDE AND JORGE BARBÉ \\ Department of Microbiology and Institute for Fundamental Biology, Autonomous University of \\ Barcelona, Bellaterra (Barcelona), Spain
}

(Received 21 May 1984; revised 4 September 1984)

\begin{abstract}
Addition of cytidine or guanosine to UV-irradiated cells of a RecA ${ }^{+}$strain of Escherichia coli did not produce any effect on the induction of two SOS functions: inhibition of cell division and expression of the $u m u C$ gene. Under the same conditions adenine gave a slight increase in the induction of these two responses. In a RecA441 mutant growing at $42{ }^{\circ} \mathrm{C}$, both cytidine and guanosine inhibited these SOS functions, whereas adenine produced a large increase in their expression. Moreover, the ATP concentration of the RecA441 mutant at $42{ }^{\circ} \mathrm{C}$ showed a decrease which occurred earlier in the cells growing in the presence of cytidine or guanosine than in the absence of either compound. Adenine induced an increase of about three times the initial ATP concentration of this mutant at $42{ }^{\circ} \mathrm{C}$ which dropped quickly after $10 \mathrm{~min}$. Neither cytidine nor guanosine increased the evolution of cellular ATP in UV-irradiated cells of the $\mathrm{RecA}^{+}$strain, whereas adenine had only a slight positive effect. However, in UV-irradiated $\mathrm{RecA}^{+}$cells with and without adenine, ATP levels dropped quickly to the initial value after $20 \mathrm{~min}$. These data suggest that the influence of adenine, cytidine and guanosine on the expression of the RecA441 phenotype at $42{ }^{\circ} \mathrm{C}$ may be due to alteration of the cellular ATP concentration of this mutant.
\end{abstract}

\section{INTRODUCTION}

Damage to DNA in Escherichia coli by radiation, chemical carcinogens or any treatment that inhibits DNA replication induces a set of cellular activities known as the SOS system (for a review, see Little \& Mount, 1982). These SOS functions include inhibition of cell division, induction and reactivation of prophages, cessation of respiration and massive synthesis of RecA protein. Nevertheless, some SOS functions may be induced by some treatments but not by others (Guerrero \& Barbé, 1982; Barbé et al., 1983a), showing that expression of the SOS system is not an all-or-none response. However, all of these SOS functions depend on the rec A, lex $A$ and $s s b$ genes. Recent biochemical studies on the RecA protein have shown that it can act as a specific protease which, after activation by some signal such as single strand DNA fragments generated by DNA damage, cleaves the repressors that control phage induction (Roberts et al., 1978). The RecA protein also cleaves the product of the lex $A$ gene, which regulates the rate of transcription of the different genes involved in the SOS system (Little et al., 1981). Among the recA mutants which have been isolated and characterized, the tif- 1 mutant, renamed rec $A 441$, is one of the most extensively studied. This mutant can express RecA functions at $42^{\circ} \mathrm{C}$ even in the absence of DNA damage or arrested DNA synthesis, whereas at $32^{\circ} \mathrm{C}$ it behaves like the wild-type RecA (Gudas \& Mount, 1977).

The expression of SOS functions in the rec $A 441$ mutant at $42{ }^{\circ} \mathrm{C}$ may be affected by different conditions. The presence of adenine in the growth medium increases the SOS response of this strain at $42^{\circ} \mathrm{C}$ (Kirby et al., 1967) whereas cytidine or guanosine inhibit induction of the RecA441 phenotype (George et al., 1975). Nevertheless, no explanation for the effect of these 
Table 1 Strains of Escherichia coli K12 used in this work

Strain

AB 1157

JM12

GW1000
Genotype

$\arg E 3$ his4 thr1 proA2 leu6 thil supE44 rpsL As AB1157, but recA441 supE

As ABI 157, but Pro+Dlac(U169) galK2 ilv(ts) recA441

sfiAl $/ \mathrm{pSE} 140\left(\mathrm{Km}^{\mathrm{r}} \Phi(\right.$ umuC lacZ) $)$
Reference

Howard-Flanders \& Theriot (1962)

Castellazi et al. (1972)

Elledge \& Walker (1983)

compounds on UV-mediated induction of SOS functions in $\mathrm{RecA}^{+}$cells has hitherto been reported. We have studied the influence of adenine, cytidine and guanosine on the ATP concentration of the UV-irradiated RecA $A^{+}$strain and in the RecA441 mutant growing at $42{ }^{\circ} \mathrm{C}$, and suggest a molecular explanation for the effect of adenine, cytidine and guanosine on the expression of the RecA441 phenotype.

\section{METHODS}

Bacteria and growth conditions. Bacterial strains used in this work are listed in Table 1. Cultures were grown at $32{ }^{\circ} \mathrm{C}$ or $37^{\circ} \mathrm{C}$ with shaking. The minimal salts medium AB (Clark \& Maaløe, 1967) was supplemented with thiamin $\left(10 \mu \mathrm{g} \mathrm{ml}^{-1}\right)$, glucose $(0.2 \%, \mathrm{w} / \mathrm{v})$ and Casamino acids $(0.4 \%, \mathrm{w} / \mathrm{v})$.

UV irradiation. Cultures were grown to $2 \times 10^{8}$ cells ml $^{-1}$ in supplemented $\mathrm{AB}$ medium, and were irradiated in a glass Petri dish (10 cm diameter) with a General Electric GY1578 germicidal lamp, at a rate of $0.5 \mathrm{~J} \mathrm{~m}^{-2} \mathrm{~s}^{-1}$ (determined with a Latarjet dosimeter). After irradiation cells were centrifuged, resuspended in the same volume of supplemented $\mathrm{AB}$ medium, and incubated at the desired temperature.

Determination of cell size. Cell size was determined with a Coulter counter ZBI equipped with a $30 \mu \mathrm{m}$ orifice, as previously described (Barbé et al., 1983a).

Determination of the intracellular ATP concentration. Cell samples of $1 \mathrm{ml}$ were added to $4 \mathrm{ml} 0.025 \mathrm{M}$-Tris/ $/ \mathrm{HCl}$ buffer $\left(\mathrm{pH} \mathrm{7.75)}\right.$ and boiled in a water bath for $5 \mathrm{~min}$. The suspension was centrifuged for $10 \mathrm{~min}$ at $4{ }^{\circ} \mathrm{C}$ and $8000 \mathrm{~g}$. ATP present in the supernatant was immediately measured by the firefly luciferin-luciferase assay (Chapman et al., 1971).

$\beta$-Galactosidase assay. This was done as described by Miller (1972). Enzyme concentrations $\left(\mathrm{U} \mathrm{ml}^{-1}\right)$ were calculated from the formula given by Casaregola et al. (1982): $\left[\left(A_{420}-1.75 A_{550}\right) / 0.0075 t\right] \times$ (reaction $\mathrm{vol}$./sample vol.) where $t$ is the time of reaction (min), the $A_{550}$ corrects for the scattering by residual bacterial debris and 0.0075 is the $A_{420}$ of $1 \mathrm{nM}-o$-nitrophenol. The reaction volume was $1.75 \mathrm{ml}$ and the sample volume was $0.1 \mathrm{ml}$.

Chemicals. Casamino acids were obtained from Oxoid. Vitamins and mineral salts were purchased from Merck, and nucleosides, nucleotides and firefly luciferin-luciferase assay components from Sigma.

\section{RESULTS}

\section{Inhibition of cell division}

Changes of cell volume of $\operatorname{Rec}^{+}$strain after UV irradiation in the presence or absence of either adenine, cytidine or guanosine are shown in Fig. 1. Under these conditions, an increase in cell volume occurred in all cultures. Nevertheless, filamentation found in the UV-irradiated cultures treated with adenine is slightly higher than that shown by the cells with cytidine or guanosine added. Furthermore, UV-irradiated cells treated with either cytidine or guanosine showed the same pattern of filamentation as the cultures without any addition.

In contrast to these results, adenine produced a significant increase in the pattern of filamentation of the rec $A 441$ mutant growing at $42^{\circ} \mathrm{C}$, whereas both cytidine and guanosine prevented the temperature-dependent inhibition of cell division (Fig. 2). However, the effect of adenine on the UV-mediated filamentation of the $\mathrm{RecA}^{+}$strain is considerably less than that induced by this nucleotide on the temperature-dependent filamentation of the rec $A 441$ mutant.

\section{Induction of the umuC gene expression}

Mutations at the $u m u C$ locus make cells of $E$. coli non-mutable by UV-irradiation and chemical mutagens (Kato \& Shinoura, 1977). Thus, the $u m u C$ gene product is the best candidate 


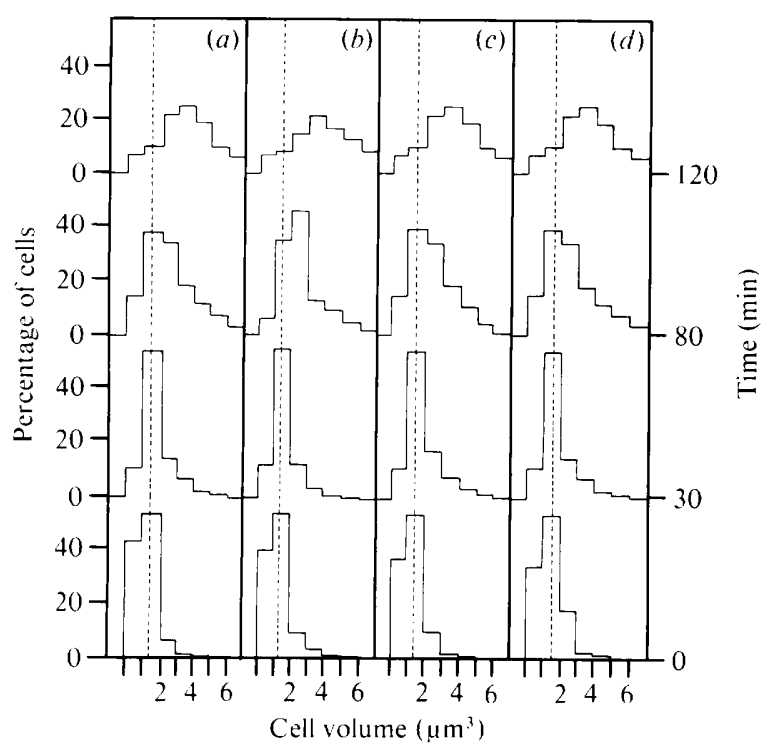

Fig. 1. Distribution of cell volumes of UV-irradiated $\operatorname{RecA}^{+}$strain growing in the absence $(a)$ or in the presence of adenine $\left(100 \mu \mathrm{g} \mathrm{ml}^{-1}\right)(b)$, cytidine $\left(300 \mu \mathrm{g} \mathrm{ml}^{-1}\right)(c)$, or guanosine $\left(350 \mu \mathrm{g} \mathrm{ml}^{-1}\right)(d)$. Measurements were made at intervals after irradiation.

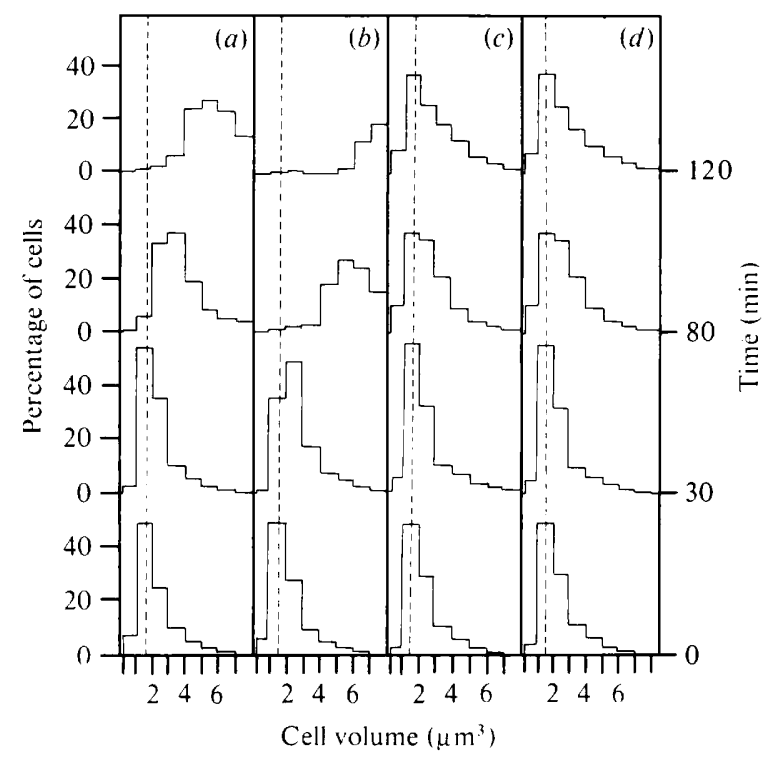

Fig. 2. Distribution of cell volumes of RecA 441 strain growing at $42{ }^{\circ} \mathrm{C}$ in the absence $(a)$ or in the presence of adenine $\left(100 \mu \mathrm{g} \mathrm{ml}^{-1}\right)(b)$, cytidine $\left(300 \mu \mathrm{g} \mathrm{ml}^{-1}\right)(c)$, or guanosine $\left(350 \mu \mathrm{g} \mathrm{ml}^{-1}\right)(d)$.

for a protein that plays a key mechanistic role in the process of error-prone repair. For this reason we studied the induction of the expression of the $u m u C$ gene in the presence of adenine, cytidine or guanosine following UV-irradiation as well as temperature treatment in a RecA441 $\mathrm{SfiA}^{-}$mutant. For this we used a low-copy-number plasmid, pSE140, which has a fusion between the $u m u C$ and lac operons (Elledge \& Walker, 1983). Adenine caused a slight increase in 


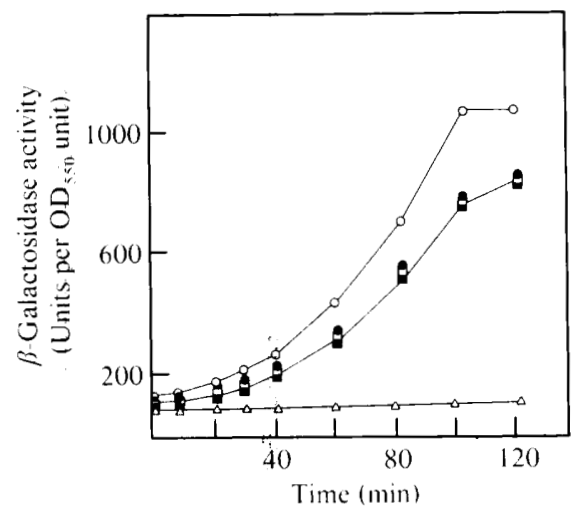

Fig. 3

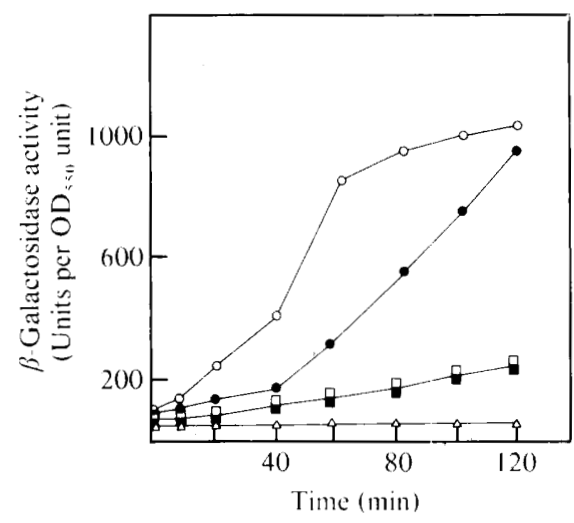

Fig. 4

Fig. 3. Induction of $u m u C$ gene expression, indicated by increased $\beta$-galactosidase, in cultures of strain GW 1000 growing at $32{ }^{\circ} \mathrm{C}$ after UV-irradiation and in the presence of adenine $\left(100 \mu \mathrm{g} \mathrm{ml}^{-}\right)(\mathrm{O})$, cytidine $\left(300 \mu \mathrm{g} \mathrm{ml}^{-1}\right)(\bigcirc)$ or guanosine $\left(350 \mu \mathrm{g} \mathrm{ml}^{-1}\right)(\square)$. umuC expression of UV-irradiated $(\square)$ and non-irradiated $(\triangle)$ cultures of the same strain growing without any addition is shown as a control.

Fig. 4. Induction of $u m u C$ gene expression, indicated by increased $\beta$-galactosidase, in cultures of strain $\mathrm{GW} 1000$ at $42{ }^{\circ} \mathrm{C}$ and in the presence of adenine $\left(100 \mu \mathrm{g} \mathrm{ml}^{-1}\right)(\mathrm{O})$, cytidine $\left(300 \mu \mathrm{g} \mathrm{ml}^{-1}\right)(\square)$ or

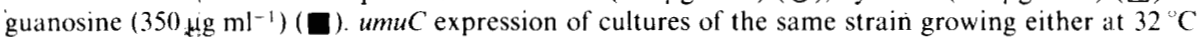
$(\triangle)$ or $42 \mathrm{C}(\circlearrowleft)$ without any addition is shown as a control.

the UV-mediated induction of $u m u C$ gene in this strain growing at $32^{\circ} \mathrm{C}$, whereas cultures treated with either cytidine or guanosine showed the same degree of $u m u C$ induction as the irradiated controls (Fig. 3). Nevertheless, the effect of adenine, cytidine and guanosine on the induction of the $u m u C$ gene in the RecA441 mutant growing at $42{ }^{\circ} \mathrm{C}$ was similar to that produced by the same compounds on the temperature-induced inhibition of cell division in this mutant. Thus, adenine gave an increase in the expression of $u m u C$ gene whereas cytidine and guanosine inhibited expression (Fig. 4).

\section{Changes in cell ATP concentration}

In previous studięs (Barbé et al., 1983b) we have shown that after UV-irradiation the Rec $\mathrm{A}^{+}$ cells show an increase in ATP concentration during the first 20 min and that afterwards ATP drops to the concentration of non-treated cells. This last ATP decrease is $\operatorname{RecA}^{+}$and LexA $\mathrm{A}^{+}$ dependent. In the same way, the RecA441 mutant shows a decrease in the ATP concentration $10 \mathrm{~min}$ after the temperature shift to $42^{\circ} \mathrm{C}$. These data led us to study the changes in the cellular ATP concentration following adenine, cytidine or guanosine addition in all UV-irradiated and non-irradiated RecA ${ }^{+}$strains and in the RecA 441 mutant growing at $42^{\circ} \mathrm{C}$. Fig. 5 shows that adenine produced during the first $20 \mathrm{~min}$ an increase of about twofold in the initial ATP concentration of non-irradiated $\mathrm{RecA}^{+}$cells. which afterwards dropped to about the initial value. Cytidine and guanosine induced a decrease of the ATP pool of the RecA ${ }^{+}$cells. Furthermore, in UV-irradiated $\mathrm{RecA}^{+}$cells, adenine only induced a slight increase in the ATP pool (Fig. 6), whereas cytidine and guanosine had a negligible effect.

The change in ATP concentration in the RecA441 mutant growing at $42{ }^{\circ} \mathrm{C}$ in the presence or absence of adenine, cytidine or guanosine is shown in Fig. 7. Adenine produced a threefold increase in the concentration of ATP, which dropped below the original concentration 10 min after adenine addition. Cytidine and guanosine produced a decrease in the ATP concentration which was greater than that shown by the untreated culture growing at the restrictive temperature. 


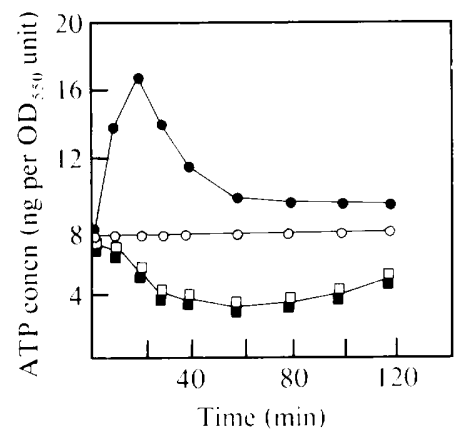

Fig. 5

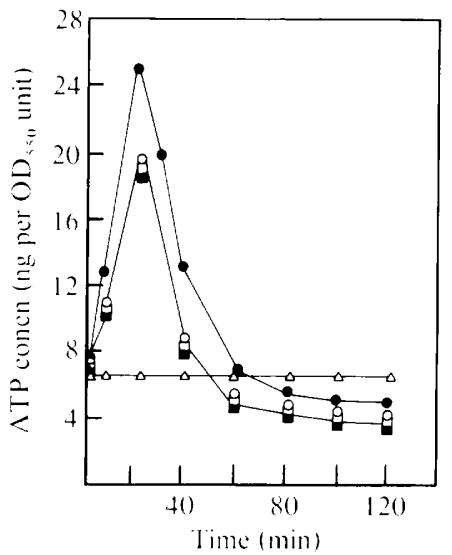

Fig. 6

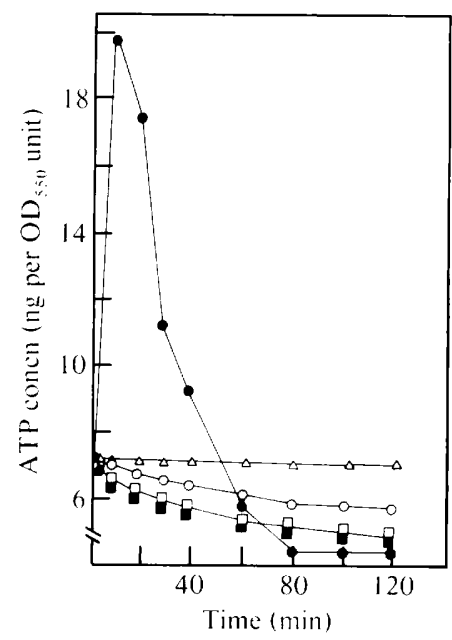

Fig. 7

Fig. 5. Changes in cellular ATP in a $\operatorname{RecA}^{+}$strain growing in the presence of either adenine $\left(100 \mu \mathrm{g} \mathrm{m}^{-1}\right)(\bigcirc)$, cytidine $\left(300 \mu \mathrm{g} \mathrm{ml}^{-1}\right)(\square)$ or guanosine $\left(350 \mu \mathrm{g} \mathrm{ml}^{-1}\right)(\square)$. The ATP concentration of an untreated culture $(O)$ is shown as a control.

Fig. 6. Changes in cellular ATP in a UV-irradiated $\mathrm{RecA}^{+}$strain growing in the presence of either adenine $\left(100 \mu \mathrm{g} \mathrm{ml}^{-1}\right)(\bigcirc)$, cytidine $\left(300 \mu \mathrm{g} \mathrm{ml}^{-1}\right)(\square)$ or guanosine $\left(350 \mu \mathrm{g} \mathrm{ml}^{-1}\right)$ ( $\square$ ). The ATP concentrations of both irradiated $(O)$ and non-irradiated $(\triangle) \mathrm{RecA}^{+}$cultures growing without any addition are shown as controls.

Fig. 7. Changes in cellular ATP in a RecA441 mutant growing at $42{ }^{\circ} \mathrm{C}$ in the presence of either adenine $\left(100 \mu \mathrm{g} \mathrm{ml}^{-1}\right)(\bigcirc)$, cytidine $\left(300 \mu \mathrm{g} \mathrm{ml}^{-1}\right)(\square)$ or guanosine $\left(350 \mu \mathrm{g} \mathrm{ml}^{-1}\right)(\square)$. The ATP concentrations of the RecA441 mutant growing either at $42^{\circ} \mathrm{C}(\mathrm{O})$ or $32^{\circ} \mathrm{C}(\triangle)$, both without any addition are shown as controls.

\section{DISCUSSION}

We present evidence to indicate that cytidine and guanosine do not have any effect on the UV-mediated expression of the two SOS functions studied here: induction of the $u m u C$ gene and inhibition of cell division. Furthermore, adenine produced a slight increase in the expression of these SOS functions after UV-irradiation. Nevertheless, in the RecA441 mutant growing at $42{ }^{\circ} \mathrm{C}$, addition of adenine, cytidine or guanosine produced a large increase and also a strong inhibition of the same SOS functions, in agreement with previous data reported by different authors (Goldthwait \& Jacob, 1964). Tessman \& Peterson (1980) suggested that the RecA441 form of the RecA protein could be an allosteric enzyme which binds both negative and positive modulators. Thus, adenine or its derivatives would be positive modulators and cytidine or guanosine would be negative ones. However, our results show that adenine produces an important increase in the ATP concentration of both non-irradiated $\mathrm{RecA}^{+}$strain and RecA441 mutant at $42{ }^{\circ} \mathrm{C}$ and that cytidine and guanosine decrease the concentration of ATP. All these data suggest that the effect of these compounds on the expression of SOS functions in the RecA441 mutant growing at $42{ }^{\circ} \mathrm{C}$ could be due to variations in the intracellular ATP concentration, since this mutant hydrolyses ATP to induce the SOS system (Barbé et al., 1983 b). Thus, adenine could stimulate SOS system induction of the RecA441 mutant because, in its presence, the cells have an ATP concentration higher than when adenine has not been added (Fig. 7). Related to this, non-irradiated $\mathrm{Rec}^{+}$cells growing in the presence of adenine show a drop in the ATP concentration about 20 min after the compound is added (Fig. 5), whereas in the RecA441 mutant growing at $42^{\circ} \mathrm{C}$, ATP decreases 10 min after adenine addition (Fig. 7). This is in agreement with the time that the mutant takes to hydrolyse the ATP when the SOS functions are induced at the restrictive temperature. Likewise, cytidine and guanosine could 
inhibit the SOS functions in the RecA441 mutant since both compounds deplete the cellular ATP pool. Under these conditions, the activated RecA441 protein would be unable to cleave the LexA repressor because this reaction in vivo requires ATP hydrolysis (Barbé et al., 1983b). The poor adenine-mediated stimulation of SOS expression of $\mathrm{RecA}^{+} \mathrm{UV}$-irradiated cells must be attributed to the slight increase of the ATP concentration induced by adenine (Fig. 6). Furthermore, cytidine and guanosine did not have any effect on the UV-mediated induction of SOS functions because neither compound affected the ATP concentration of irradiated cells (Fig. 6). In this context, the possible effect of cytidine and guanosine on the ATP pool of UVirradiated $\mathrm{RecA}^{+}$cells must be overcome by the strong UV-dependent ATP increase which is produced in the irradiated cells by metabolism of DNA degradation products (Barbe et al., 1983 ; Guerrero et al., 1984). However, our hypothesis also explains the observation (Kirby et al., 1967) that UV-irradiation reverses the cytidine- and guanosine-mediated inhibition of constitutive expression of SOS functions at $42^{\circ} \mathrm{C}$ in the RecA441 mutant.

We thank Dr M. Blanco and Dr S. J. Elledge for their generous gift of several strains. We acknowledge the help of the Comisió Interdepartamental de Recerca i Innovació Tecnològica of the Generalitat de Catalunya for a grant for the purchase of equipment. This work was partially supported by a grant of the Comision Asesora de Investigación Científica y Técnica, Spain.

\section{REFERENCES}

Barbé, J., Vericat, J. A. \& Guerrero, R. (1983a). Discriminated induction of SOS functions in Escherichia coli by alkylating agents. Journal of General Microbiology 129, 2079-2089.

Barbé, J., Villaverde, A. \& Guerrero, R. (1983b). Evolution of cellular ATP concentration after UVmediated induction of SOS system in Escherichia coli. Biochemical and Biophysical Research Communications 117, 556-561.

Casaregola, S., D'Ari, R. \& Huisman, O. (1982). Quantitative evaluation of $r e c A$ gene expression in Escherichia coli. Molecular and General Genetics 185, 430-439.

Castellazzi, M., George, J. \& Buttin, J. (1972). Prophage induction and cell division in $E$. coli. I. Further characterization of the thermosensible mutation tif-1 whose expression mimics the effect of UV irradiation. Molecular and General Genetics 119 , 139-152.

Chapman, A. G., Fall, L. \& Atkinson, D. E. (1971). Adenylate energy charge in Escherichia coli during growth and starvation. Journal of Bacteriology 108, 1072-1086.

Clark, D. J. \& MAaløe, O. (1967). DNA replication and the division cycle of Escherichia coli. Journal of Molecular Biology 23, 99-112.

Elledge, S. J. \& Walker, G. C. (1983). Proteins required for ultraviolet light and chemical mutagenesis in $E$. coli: identification of the products of the umuC locus of Escherichia coli. Journal of Molecular Biology 164, 175-192.

George, J., Castellazzi, M. \& Buttin, G. (1975). Prophage induction and cell division in Escherichia coli. III. Mutations $s f i A$ and $s f B$ restore division in tif and lon strains and permit expression of mutator properties of tif. Molecular and General Genetics 140, 309-322.

GoldThwaIt, D. \& JaCOB, F. (1964). Sur le mécanisme de l'induction du dévelopement du prophage chez les bactéries lysogénes. Compte rendu de l'Académie des sciences 259, 661--664.

GudAs, L. J. \& MouNT, D. W. (1977). Identification of the recA (tif) gene product of Escherichia coli. Proceedings of the National Academy of Sciences of the United States of America 74, 5280-5284.

Guerrero, R. \& BARBE, J. (1982). Expression of recAgene dependent SOS functions in Salmonella typhimurium. Antonie van Leeuwenhoek 48, 159-167.

Guerrero, R., Llagostera, M., Villavierde, A. \& BARBÉ, J. (1984). Changes in ATP concentration in Escherichia coli during induction of the SOS system by mitomycin $\mathrm{C}$ and bleomycin. Journal of General Microbiology 130, 2247-2251.

Howard-Flanders, P. \& Theriot, L. (1962). A method for selecting radiation sensitive mutants of Escherichia coli. Genetics 47, 1219-1224.

Kato, T. \& Shinoura, Y. (1977). Isolation and characterization of mutants of Escherichia coli deficient in induction of mutations by ultraviolet light. Molecular and General Genetics 156, 121-131.

Kirby, E. P., Jacob, F. \& Goldthwait, D. (1967). Prophage induction and filament formation in a mutant strain of Escherichia coli. Proceedings of the National Academy of Sciences of the United States of America 58, 1903-1910.

Little, J. W. \& Mount, D. W. (1982). The SOS regulatory system of Escherichia coli. Cell 29, 11-22.

Little, J. W., Mount, D. W. \& Yanisch-Perron, C. R. (1981). Purified lexA protein is a repressor of the recA and lexA genes. Proceedings of the National Academy of Sciences of the United States of America 78, 4199-4203.

MilleR, J. H. (1972). Experiments in Molecular Genetics. New York: Cold Spring Harbor Laboratory.

Roberts, J. W., Roberts, C. W. \& Craig, N. L. (1978). Escherichia coli recA gene product inactivates phage $\lambda$ repressor. Proceedings of the National Academy of Sciences of the United States of America 75, 4714-4718.

Tessman, E. \& Peterson, P. K. (1980). tif-Dependent induction of colicin E1, prophage Lambda, and filamentation in Escherichia coli K-12. Journal of Bacteriology 143, 1307-1317. 